\title{
PROTECTIVE EFFECT OF TRAUMATIC LESIONS ON RHEUMATOID ARTHRITIS
}

\author{
BY \\ J. S. KAMERMANN \\ Centre for Rheumatic Diseases, Amsterdam, Netherlands \\ (Medical Director: Dr G. van Dam)
}

Jacqueline (1953) reported the case of a man who had developed a paresis of the right arm and leg when 2 years old; at the age of 41 , he developed articular disorders which developed into a severe rheumatoid arthritis, but only on the side not affected by the hemiplegia.

Thompson and Bywaters (1962) reported four patients with hemiplegia due to meningioma, cerebral thrombosis, syphilis, and cerebrovascular disease respectively. Later in life, these patients developed rheumatoid arthritis on the non-hemiplegic side of the body, and in the second and fourth of these cases, a few joints on the hemiplegic side which had retained some locomotor and weightbearing function were also affected. The sparing mechanism in the other cases was therefore considered to reside in the non-use of the joints on the hemiplegic side. No other explanation (of a vasomotor or neurological nature) could be found.

The same protective effect has also been observed in arthrosis, with lesions of the higher as well as of the lower motor neuron.

The protective effect of lesions of the lower motor neuron in rheumatoid arthritis has not hitherto been described, and we believe that the case reported below is an example of this phenomenon.

\section{Case Report}

A woman aged 57 years, who in 1954 had suffered an accident with comminuted fractures of the right elbow in several places, came to our clinic in 1964. After the accident it had been found that the ulnar nerve was contused in two places. The loose bone fragments (distal part of the humerus and proximal part of the ulnar and the radius) had been removed, so that the elbow joint completely disappeared, and a pseudarthrosis developed (Fig. 1); 4 months after the accident, the median nerve proved to be neurologically normal, but the ulnar nerve showed a complete, and the radial nerve an incomplete, degeneration when tested electrically. From 1960 to 1963 the patient suffered from diffuse rheumatic symp-

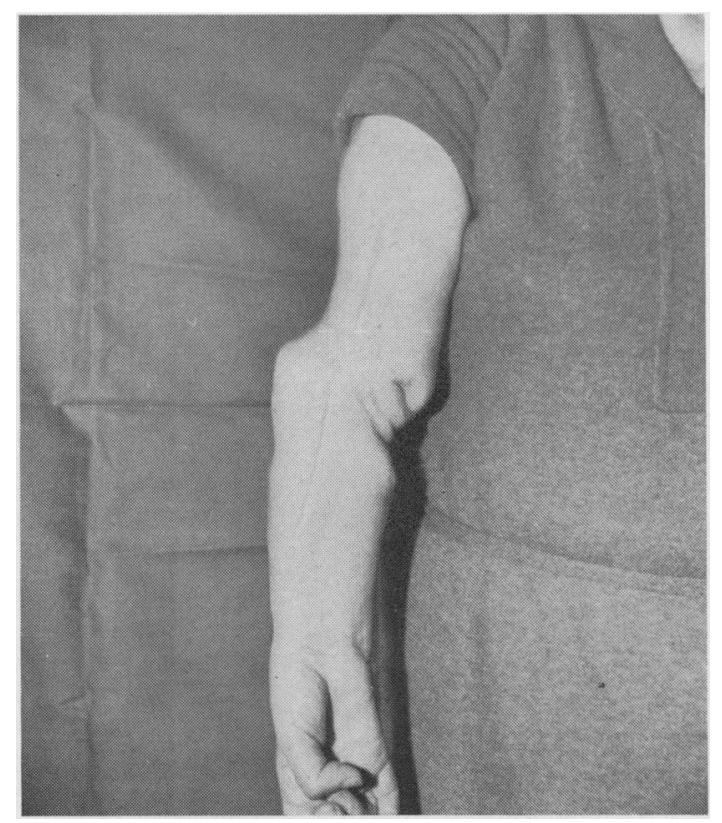

Fig. 1.-Appearance of right arm after accident.

toms, which she treated herself at home with a quartz lamp.

In December, 1964, she consulted us for pain in the left shoulder, elbow, and wrist, and swelling and pain in the finger joints of the left hand and the metatarso-phalangeal joints of both feet. The left hand was stiff in the morning, but the stiffness was decreased by a warm bath.

Examination.-She was an apparently healthy woman. There was some tenderness on pressure at the upper margin of the left trapezius muscle. No abnormalities were found in the left shoulder, elbow, or wrist, but there was thickening of the 2 nd and 5 th metacarpo-phalangeal joints and the 2nd and 4th proximal inter-phalangeal joints. There was some pressure pain on the 2 nd 
proximal inter-phalangeal joint. The patient could make a good firm fist with the left hand.

No signs of rheumatism could be found in the right elbow and hand.

The functional state of the right "elbow" (passive movement) was: flexion $70^{\circ}$ and extension $180^{\circ}$. No rotation was possible. An abnormal finding was that the forearm could be passively adducted to $90^{\circ}$. Active movement was impossible because not a single muscle had an origin or insertion, and this made the good right hand grasp comparatively useless to the patient. In the forearm and hand she was unable to use the muscles innervated by the ulnar nerve, which did not respond to electrical stimulation. In the territory of the ulnar nerve, the sensitivity at the cutaneous surface was lost (i.e. in the 5 th finger and half of the 4th finger), although deep sensitivity in these fingers was normal. No reflexes could be evoked.

The radial arteries of the right and left arms were the same.

Laboratory Findings.-E.S.R. $8 \mathrm{~mm} . / \mathrm{hr}$; R.A. test +; Waaler-Rose test $1: 16$.

$X$ Rays.-The left hand (Fig. 2) showed erosions of the ulnar styloid and soft tissue swelling affecting the 2 nd and 4th proximal inter-phalangeal joints.

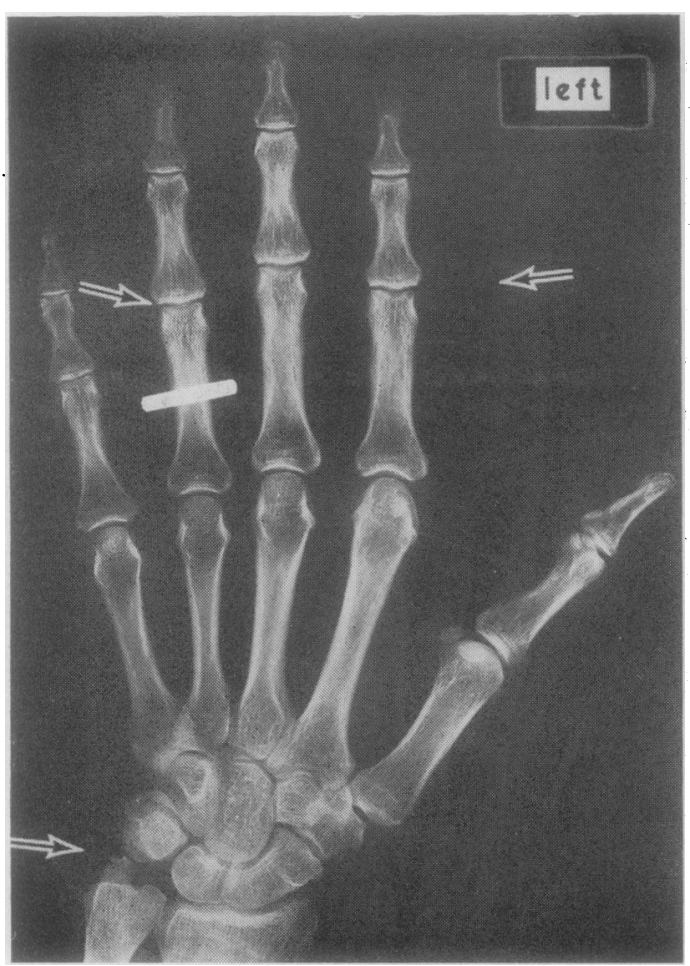

Fig. 2. $-X$ ray of left hand.
The right hand (Fig. 3) showed diffuse osteoporosis $\overline{3}$ with loss of bone in the cortical shaft. There was a doublecontoured outline to the bones of the wrist and carpus, as is sometimes seen after ischaemia of the hand, with apparent narrowing of joint space due to basal ossification $\stackrel{5}{+}$ of cartilage. There was loss of subchondral cortical bone in the head of the third proximal phalanx on the radial $\bar{\sigma}$ side, but no sign of soft tissue thickening. The feet $\frac{\bar{\sigma}}{\bar{D}}$ showed no abnormalities.

Diagnosis.-Rheumatoid arthritis of the left hand (the diagnostic criteria were fulfilled).

Progress.-The patient showed rapid improvement $\overrightarrow{\vec{\omega}}$ during treatment with the quartz lamp. At the time of writing, the only remaining abnormality is swelling of the metacarpophalangeal joint of the 2nd finger on the left hand (Fig. 4, opposite). The grasping function of the right $\mathrm{Gr}$ hand is very good, but the patient cannot do much with this hand, as she is unable to use the "elbow".

\section{Comment}

The left hand of this patient (who was originally $\vec{c}$ right-handed) is greatly overtaxed, and this suggests< that the "protective" effect of the paralysis is due $\vec{\bullet}$ rather to the disuse of the right hand than to lack of

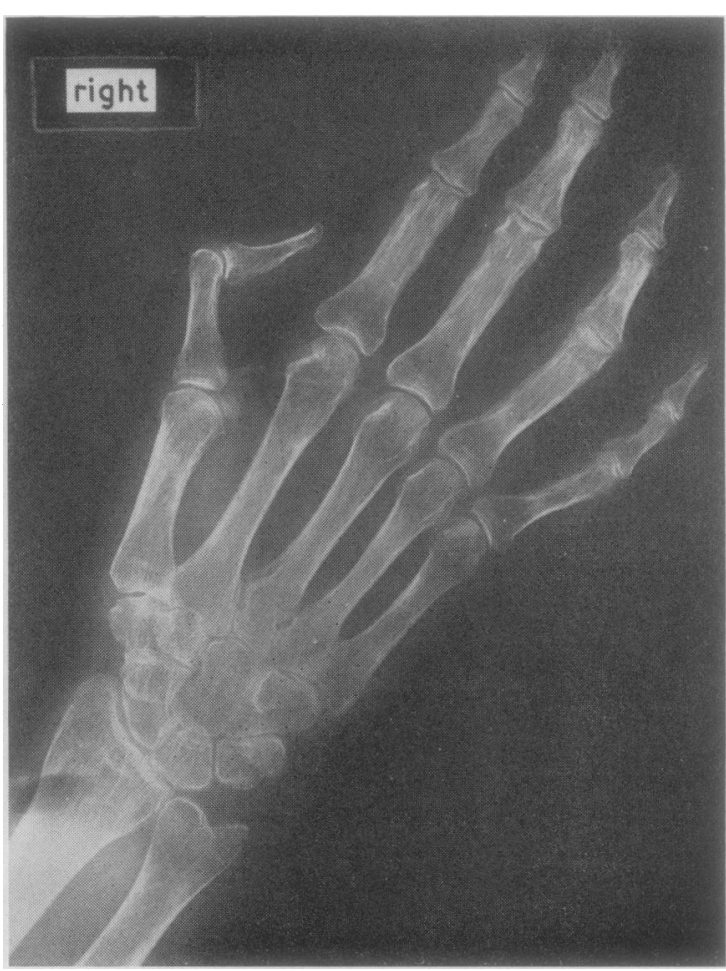

Fig. 3. $-X$ ray of right hand. 


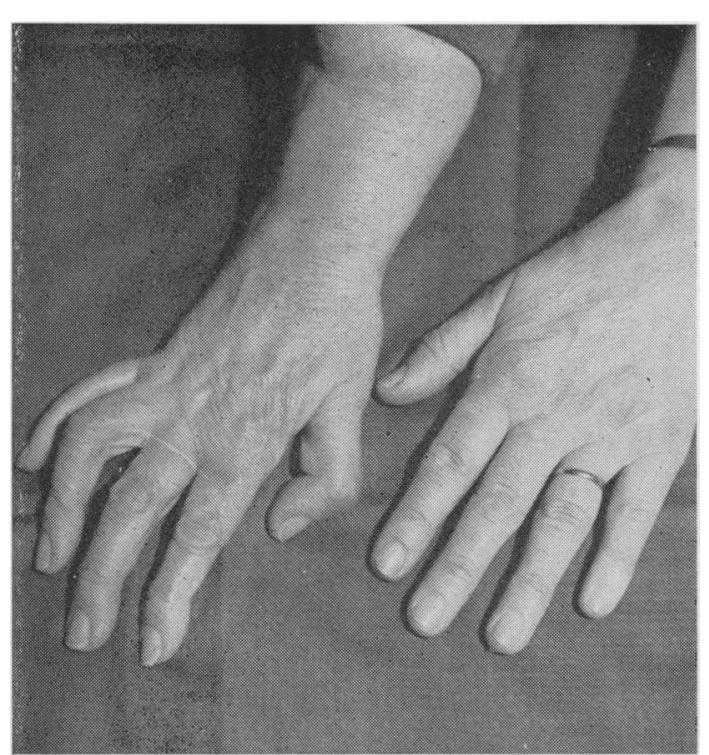

Fig. 4.-Appearance of right and left hands.

innervation. The fact that deep sensation was normal, indicates that the innervation of the joints was adequate, and since rheumatoid arthritis affects the joints first, this also supports the view that the protective effect is due not to the neurological lesion but to the comparative disuse of the right hand.

\section{Summary}

The case is reported of a woman aged 57 years, who in 1954 had sustained a serious accident as a result of which the right elbow joint was replaced by a pseudarthrosis, with complete loss of the ulnar nerve and partial loss of the radial nerve. The patient accordingly lost the function of the right elbow, and could make little use of the remaining adequate function of the right hand. In 1964, she developed rheumatoid arthritis of the left hand, but the condition did not appear in the right hand.
The protective effect of the traumatic lesion in rheumatoid arthritis is attributed to the comparative disuse of the right hand rather than to the neurological lesion.

I gratefully acknowledge the help of Dr Oesterreicher, who carried out the neurological examination.

\section{REFERENCES}

Jacqueline, F. (1953). Rev. Rhum., 20, 323.

Thompson, M., and Bywaters, E. G. L. (1962). Ann. rheum. Dis., 21, 370.

\section{L'effet protecteur des lésions traumatiques sur l'arthrite rhumatismale}

\section{RÉSUMÉ}

On signale le cas d'une femme âgée de 57 ans qui, en 1954, avait subi un grave accident à conséquence duquel l'articulation de son coude droit avait été remplacée par une pseudarthrose, associée à la perte du nerf cubital et $\overleftarrow{\complement}$ d'une partie du nerf radial. La fonction du coude droit était perdue et pour cette raison la malade se servait peu $\vec{\bullet}$ de ces fonctions qui avaient demeuré intactes à la main droite. En 1964 elle a développé l'arthrite rhumatismale o. à la main gauche, mais non pas à la main droite.

On attribue l'effet protecteur de la lésion traumatique dans l'arthrite rhumatismale à l'usage réduit de la main droite plutôt qu'à la lésion neurologique.

\section{El efecto protector de las lesiones traumaticas respecto a la artritis reumatoide}

\section{SUMARIO}

Se señala el caso de una mujer de 57 años que, en 1954, sufrió un accidente grave a consecuencia del cual la articulación de su codo derecho fué sustituida por una seudartrosis, con la pérdida del nervio cubital y de una parte del nervio radial. La función del codo derecho desapareció y la enferma se sirvió poco de aquellas funciones que quedaron intactas en la mano derecha. En 1964 desarrolló la artritis reumatoide en la mano izquierda, sin implicación de la mano derecha.

El efecto protector de la lesión traumática en la artritis reumatoide se atribuye al desuso relativo de la mano derecha más bien que a la lesión neurológica. 